Candidate of Philological Sciences, Associate Professor of the Chair of Foreign Languages for Science Faculties, Odessa I. I. Mechnikov National University, French Boulevard, 24/26, Ukraine, Odessa, 65058; tel..: + 38048 2635745; e-mail: tkachenko_anna_0@mail.ru; ORCID ID: 00000003-0274-8752; DOI: https://doi.org/10.18524/2410-3373.2019.22.195032

\title{
HISTORICAL PRINCIPLES OF THE TERM CHREMATONYM GENESIS AND THE BORDERS OF CHREMATONYMIC FIELD
}

\begin{abstract}
It became necessary to investigate the problem concerning the study of the proper names of unique things - chrematonyms. In this paper we offer several viewpoints of significant Slovak and foreign (Czech, Polish, Russian and German) onomasticians regarding the problem of specifying and defining chrematonyms in the onymic system. At the same time, we offer our own suggestion for the classification of chrematonyms. 1854 chrematonyms resulted in discovery of common ways in the process of their generating and functioning. There is no general notion about the borders of chrematonymy in Ukrainian onomastic science. The attention is paid to the fact that the borders of chrematonymic field are open. The article stresses the importance of chrematonomastic terms establishment, so that this field of onomastics can be an equal partner of other disciplines and at the same time fulfill the denomination needs of other languages. The purpose of the work is the analysis of the existing in linguistics definitions of the term chrematonym, their comparison and systematization, and their distinguishing between chrematonym classes. Also the analysis of different ways of proper names investigation is carried out. The definition of the term chrematonym is suggested and the classification of chrematonyms is created. The subject of the study is English chrematonyms from the view point of their classification and systemization. The object of the study is English onymic system. The research states that one of the most important facts of naming is the influence of the surrounding social and physical environment and the owner's desire to fix the extraordinarity of a definite type. Choosing and giving the name to the object, a man more often doesn't create anything new; he just gives it a name, trying to bring it to eternity. One of the most ancient traditions that has been practically used for so long is the owner's personal name application. The article also determines and enumerates the functions of onyms, especially of chrematonyms. They are as follows: singling out, characterizing, identifying and signifying. Proper names of unique objects exist to perform a background for a man and his life, picking out definite features, reflecting his process of thinking; to show the objective reality; to open up the speaker's inner world, his creative personality. The method of systematization is used in the work. Summing up, the individual chrematonimic field comprises 7 subfields, 39 subsubfields and 6 microfields (segments). As a result of the investigation, the definition of the term chrematonym was suggested and the classification of chrematonyms was created.
\end{abstract}

Key words: onym; chrematonyms; chrematonomastics.

\section{INTRODUCTION}

One of the most important factors that determine the necessity for a title of an object to appeare is the influence of the surrounding environment and the desire of the owner to fix the exclusivity of a particular product. When choosing a name for an item one often does not invent anything new but simply gives the name trying to 
eternalize it. The use of a particular proper name is one of the most ancient traditions that has long come into practice. The aim of the paper is to analyze the existing in onomastics definitions of the term chrematonim, their comparison and systematization, and their distinguishing between chrematonym classes. The study is motivated by 2 reserarch questions: 1) historical principles of the term chrematonym genesis; 2) the borders of the chrematonymic field. To examin these issues we studied the existing traditional viewpoints on the problem of the outstanding onomotologiests. The issue of the historical principles of the term cgrematonym genesis is a fundamental question in onomastics currently. We suggest that a new generation of research in this area needs to address the extended borders of chrematonymic field. Prior studies offer a descriptive account of chrematonymic problem and indicate the lack of a stable definition and division into groups within a chrematonymic field.

\section{BACKGROUND AND MOTIVATION}

To date, no systematic investigation has considered the problem of chrematonyms, therefore we conducted in-depth case study of the issue and fulfilled a comparative analysis of the given chrenatonym term definitions and explored their roles and functions in onomastics.

\section{DISCUSSION}

As noted by a famous English linguist D. Crystal (2006) in onomastics there is a phenomenon of the ability to acquire a proper name - the process of nameability the process of obtaining a name of a thing basing on its close relation to our life. In fact any thing of objective reality can be named. O. Superanskaya (1973) identifies the functions of a proper name with the general functions of the language and distinguishes four basic ones: communicative, appellative, expressive and deixis. According to $\mathrm{Yu}$. Karpenko (2008) nomination, identification and differentiation are the three aspects of the main and major function of proper names and all other functions of proper names, in particular informative and emotional, are supposed to be optional and less specific. In our opinion different classes of onyms have active or passive, namely, extra peripheral functions. 
We schould state that chremotonyms also have additional functions. According to their purpose chrematonyms play four roles: isolating, characterizing, identifying, and signifying. Proper names of the unique objects exist in order to create a background for the person and his life distinguishing the individual details, reflecting the process of his thinking, hobbies, customs and observations; depicting objective reality; revealing the inner world of the speaker and his creative personality.

A prominent Czech onomatologist M. Garvalik $(2007,6)$ is inclined to believe that great difficulties arise when it is necessary to use and compare the terms of different onomastic schools. A similar situation has arisen in chrematology.

There are four more or less well-known European onomastic schools: PolishCzech, Russian, Ukrainian and German ones that study and analyze proper names. However, it is worth mentioning that as far as these scientific schools are geographically distant from each other so the results of their research are different. For instance, Polish onomatologist Ch. Kosil (2003) refers proper names of some material industrial or handmade things to chrematonyms both singular and serial (Kosil, 2003, 370); Czech onomatologist L. Cuba (2003) also attributes ideonyms and ergonyms to chremanonyms, but in our opinion chrematonyms are a component of pragmatonyms, not ideonyms in any case (Cuba, 2003, 376). Another Czech onomatologist M. Knappova (1995) introduced the term economic chrematonyms to onomastic science(Knappova, 1995, 152-157); Slovak onomatologist M. Maytan (2003) mentions that the names of the epochs are also considered as chrematonym, but it should be stressed that there is a separate class of chrematonyms for these onyms (Maytan, 2003, 375); G. Dorion and J. Poirier (1975) characterize chrematonyms as proper names of vehicles - poreionyms; English-speaking countries onomatologists do not distinguish chrematonyms as they are, studying primarily anthroponyms (Mike Campbell) and toponyms (Richard Coates, Eilert Ekwall, Margaret Gelling, Oliver Padel, Robert L. Ramsay, Henry Schoolcraft, Albert Hugh Smith, George R. Stewart, Isaac Taylor, William J. Watson, Craig Weatherhill).

The viewpoints of the Ukrainian onomastic school on the problem of chrematonomastics can be compared with the viewpoints of the Russian school - 
they are almost similar. In the study of the basic terminological issues of chrematology Russian onomatologists Olga Superanskaya and Natal'ya Podol'skaya consider chremanonyms as the proper names of separate non-living material objects produced or obtained by humans (weapons, dishes, jewelry, musical instruments) (1973, 146). Ukrainian researchers are inclined to such an interpretation of the problem and define chrematonyms (from the Greek. shrema - thing and onym name, title) as proper names of certain material objects - ships, diamonds etc., as well as the articles of spiritual culture - the names of works of art, musical plays, masterpieces of painting, films etc. (Philological Encyclopedia, 2007, 129). In this case it should be noted that a given definition completely changes the meaning of the term and mixes up different sectors. The titles of fiction works, musical plays, masterpieces of paintings and films should be attributed to ideonyms different categories of names that have their denotates in the mental, ideological and artistic spheres of human activity (Podol'skaya, 1988, 61). Mainly, chrematonyms are refered to pragmatonyms those that have their denotates in pragmatic sphere of human being (Podol'skaya, 1988, p. 110).

In Slavonic onomastic science the emergence of the term chrematonym can be dated to 1966 in the article written by I. Honl $(1966,5)$ in which the author lists various classes of onyms (anthroponyms, zoonyms etc.) and distinguishes chrematonyms that are signified as proper names of things. Exactly this time can be considered as the birth date of chrematonomastics as this is a much younger branch is called in Czech and Polish onomastic schools.

The further development of the issue was dated to the year 1989 in the publication of Majtan's (1989) work in which the linguist provides his own typology of the chromatonymic proper name lexicon. We consider it necessary to emphasize that this classification is a mixture of onyms from different classes and is not established or fixed (for example, the names of events, organizations that are considered to be ergonyms, which are at present distinguished as a separate class, were referred to chrematonyms). It should be highlighted that since that time the interpretation of the term chromatonym becomes clear and stands out as an independent class of proper names. Another researcher identifies ergonyms, 
ideonyms, chrononyms as chrematonyms that is obviously a false statement and a misunderstanding today. However, rather valuable and correct are the clues to determine that chrematonyms are the proper names of seriate products (Šmilauer, 1976, 109-111). This definition is confirmed in later research of the problem (Šramek, 1999, 165).

Czech onomatologist L. Cuba (1999) is considered to be one of the prominent researchers of the chrematonymic lexicon. The researcher is inclined to believe that chrematonyms are the proper names of human handicrafts and that these names are not fixed in time and space (Cuba, 1999, 103). In his work the author extended the boundaries of chromatonomastics and distinguished his own components of this class according to which the proper names of holidays, battles, revolutions, congresses, medals, heraldic symbols, authorities, state institutions, economic bodies, military organizations, diplomatic acts are referred to chrematonyms (Cuba, 1999, 103 - 123). In our opinion, myriad of proper names were analyzed but unfortunately none of the subgroups has been standardized or unified.

Equally well known in chrematonomastics is a Polish linguist Ch. Kosyl (1993) who analyzed various onyms on the bases of their characteristics and divided the chrematonyms into two subgroups. The first one was divided between proper names of makeup products, proper names of alcohol and tobacco products, proper names of military objects. The second group covered proper names of business equipment and those chrematonyms that we consider to be ergonyms due to the established tradition (Kosyl, 1993, 440 - 444).

Contemporary viewpoints on the issue of chrematonomastics can be traced in the works of Polish (Jakus-Borkowa) and Slovak (OGarančovská) onomatologists. According to E. Yakus-Borkova's (2007) opinion, who conducted the analysis and paid more attention to the space proper names, chrematonyms can be divided into three groups: 1) proper names of cultural pieces (nonmaterial) related to the Universe investigation; 2) proper names of technical astronomical apparatus; 3) proper names of onland equipment used in space exploration (Jakus-Borkowa, 2007, 57). L. Garankovskaya (2009) proposes her own newest classification according to which 
the researcher attributes proper names of single or serial products to chrematonyms: ergonyms (proper names of associations of people), chrononyms (proper names of segments of time), actionyms - proper names of conferences (performances, events), documentonyms - proper names of documents (proper names of acts, laws, documents), phaleronyms (proper names of medals, titles, posters) (Garančovská, 2009, $97-98)$.

According to the definition N. Podolskaya (1988) a chrematonym is considered viewed as a proper name of a unique handmade object of material culture produced or obtained by a human-being (Podolskaya, 1988, 146). The Soviet onomatologist O. Superanskaya (1973) gives one of the first clearly formulated and outlined classifications of proper names in her work. According to this classification the following classes can be distinguished in the onymic landscape: anthroponyms, toponyms, zoonyms, cosmonyms, astronyms (the study of proper names of individual celestial bodies: stars, planets, comets, asteroids etc.) altogether with astrotoponyms (the study of space cosmographical names) chrononyms, chrematonyms, mythonyms etc. (Superanskaya, 1973, 173). According to the researcher's viewpoint chrematonyms are the proper names of certain nonliving objects. This class also includes the names of weapons and musical instruments. In this case it should be emphasized that "the name of the manufacturer of such instruments may be a unique means of individualization, but it does not give a proper name to this thing" (Superanskaya, 1973, 190). For example, the creators of the weapons are armourers, and the name is given directly by the owner, or it is given due to some properties the sword of the Sparkling and the Icy Death or the place of discovery - the Thames Sword which was found at the bottom of the River Thames, in London.

Considering this issue we found out a recent and newest classification proposed by Ukrainian onomatologist M. Torchinskii. According to it chrematonyms are divided into four main sectors: jewelry names, unique names, collection names, and emblem names, each of these includes several more subsectors (Torchinskii, 2008, 193 - 196).

\section{RESULTS}


While the process of a thorough analysis study and investigation of the definitions and classifications of the chrematonyms suggested by various linguists, we can draw the following conclusions and pose the following tasks: firstly, to clearly define the term by combining the above mentioned; secondly, to create our own classification of the chrematonymic vocabulary, taking into account the above proposed commentaries; thirdly, to unify the ancient chematonymic terminology and to create a new one basing on the discovery of new subgroups. Factually, we reckon that chrematonyms are 1) a set of proper names of individual unique objects created by a man or nature 2) similar or identical proper names of a series of objects with the same denotates (one chrematonym may indicate a series of identical objects, one class, or brand: the Oscar Award - there is a large number of figures, and the name of the award is general).

We conducted the analysis of 1854 chrematonyms and created the newest systematization of chrematonymic field. The data obtained enables us to differentiate all the chrematonyms into 7 sectors (275 proper names of weapons, 184 proper names of house equipment, 366 proper names of emblems, 192 proper names of collections, 367 proper names of vehicles, 197 proper names of unique things, 273 proper names of jewelry items), and some of which are further subdivided into 39 sub-sectors and 6 segments (Tkachenko, 2012).

\section{CONCLUSION}

Finally, we may conclude that the number of sectors is not equal; their boundaries are changeable and can be moved in the process of scientific knowledge. The prospects of the future research in this direction are determined as follows: to stydy the chrematonyms in the context of any cultural community and expand the sectors of the chrematonymic field.

\section{REFERENCES}

1. Crystal, D. (2006). The Cambridge Encyclopedia of the English Language. London: Cambridge University Press, 2-nd ed. 
2. Cuba, L. [Cuba L.] (1999). Pojmeniváni lodi z původního chrématonyma (př́padně z apelativa a $\mathrm{z}$ jiného druhu vlastních jmen, které souvisejí s chrématonymy) Acta Onomastica. Věnovăno k 100. Výroči narozeni Ph. Dr. Jana Svobody, Dr. Sc. Ročník 40, 103 - 123.

3. Dorion, H. \& Poirier, J. (1975). Lexique des termes utiles a l'etude des noms de lieux. Quebec: French and European Publications, Inc.

4. Holn, I. [Honl I.] (1966). O tyronymech - názvech sỳrů. Zpravodaj Místopisné komise. ČSAV 7 , $5-9$.

5. Harankovska, L. [Garančovská, L.] (2009). Vymedzenie chrématoným v onymickom systéme. Acta Onomastica, Ročník 50, Praha, 88 - 101.

6. Yakus-Borkowa, E. [Jakus-Borkowa, E.] (2007). Acta Onomastika. Ročník 48, Praha, 54 - 71.

7. Knappova, M. [Knappová, M.] (1995). Proměny hospodářských chrématonym. Termina 94. Liberec 21-23 června 1994. Konference o odborném stylu a terminologii: sborník př́spěvkì, Liberec, $152-157$.

8. Kosyl, Ch. [Kosyl C.] (1993). Chrematonimy: Encyklopedia kultury polskiej XX wieku. Wspótczesny język polski [J. Bartmiński (ed.)], Wroclaw, 440 - 444.

9. Majtan, M. [Majtan M.] (1989) Klasifikácia chrématonimie. Chrématonima z hlediska teorie a praxe. Sborník z 3. celostátního semináře "Onomastika a škola”, Ústí nad Labem 21.-22.6.1988, Brno, 7 - 13.

10. Slov'yanska Ensticlopesiya [Słowiańska onomastika. Encyklopedia]. (2002). Warszawa: Kraków: Wyd-wo Naukowe Warszawskie, T. 1-2.

11. Shmilauer, V. [Šmilauer V.] (1976). Tř́děni vlastních jmen (teze). V. zasadnutie Medzinárodnej komisie pre slovanskú onomastiku a V. slovenská onomastická konferencia (Prě̌ov 3. - 7. Mája 1972) / [M.Blicha - M.Majtan (eds.)], Zborník materiálov. Bratislava, 109 - 111.

12. Shramek, R. [Šramek, R.] (1999). Ǔvod do všeobchej onomastiky. Brno.

13. Harvalyk, М. [Гарвалик М.] (2007). К вопросу о современной ономастической терминологии. Вопросы ономастики, № 4, Moscow, 5 - 13.

14. Karpenko, Yu. [Карпенко Ю. О.] (2008). Literaturna onomastyka: zbirnyk statei. [Літературна ономастика: збірник статей].Odesa: Astroprint.

15. Philological Encyclopedia. [Філологічна енциклопедія] (2007). Edited by: O. I.Skopnenko, T. V.Tsymbaliuk, Kiiv: Dovira.

16. Podolskaya, N. [Подольская Н. В.] (1988). Slovar' russkoi onomastichenkoy terminiligii. [Словарь русской ономастической терминологии]. $2^{\text {nd }}$ Ed. Moscow: Nauka.

17. Superanskaya, О. [Суперанская О. В.] (1973). Obschaya teoriya imeni sobstvennogo. [Общая теория имени собственного]. Moscow: Nauka.

18. Tkachenko, G. [Ткаченко Г. В.] (2012). Anglomovni hrematonimy yak linvokognitivni fenomeny kartiny svitu [Англомовні хрематоніми як лінгвокогнітивні феномени картини світу]: Thesis. Odesa: Phenix.

19. Torchinskii, М. [Торчинський М. М.] (2008). Struktura onimnogo prostoru ukrayinskoyi movy: Monograph. [Структура онімного простору украӥнської мови: монографія].

Chmel'nitskii: Avist.

\section{ТКАЧЕНКО Ганна Володимирівна}

кандидат філологічних наук, доцент кафедри іноземних мов природничих факультетів Одеського національного університету імені I. I. Мечникова, Французький бульвар, 24/26, 
Одеса, 65058, Україна; тел..: + 38048 2635745; e-mail: tkachenko_anna_0@mail.ru;

ID: 0000-0003-0274-8752

\title{
ПРОБЛЕМАТИКА ХРЕМАТОНІМІВ: ІСТОРИЧНІ ЗАСАДИ ПОЯВИ ТЕРМІНА ХРЕМАТОНІМ І ДІАПАЗОН ХРЕМАТОНІМНОГО ПОЛЯ
}

\begin{abstract}
Анотація. В останній час актуалізувалася проблематика, що пов'язана 3 вивченням власних назв унікальних предметів - хрематонімів. Предметом нашої розвідки становлять англійські хрематоніми з позиції їх класифікації та систематизації. Об'єктом - англійська онімна система. В українській ономастичній науці досі не існує загальноприйнятого уявлення про межі хрематонімії. Метою даної статті $\epsilon$ аналіз існуючих у лінгвістиці визначень терміна хрематонім, зіставлення їх, уніфікація та стандартизація, виокремлення розрядів і класів хрематонімів, а також спроба простежити за змінами розрядів від класичного до сучасного стану. Наукова актуальність даної роботи полягає у новому ракурсному вивченню проблеми хрематонімії. В статті пропоновано визначення терміна хрематонім та відтворена класифікація розрядів хрематонімів.
\end{abstract}

Ключові слова: онім; хрематоніми; хрематонімія.

\section{ТКАЧЕНКО Анна Владимировна}

кандидат филологических наук, доцент кафедры иностранных языков естественных факультетов Одесского национального университета им. И. И. Мечникова; Французский бульвар, 24/26, Одесса, Украина, 65058; тел..: + 38048 2635745; e-mail: tkachenko_anna_0@mail.ru; ORCID ID: 0000-0003-0274-8752

\section{ПРОБЛЕМАТИКА ХРЕМАТОНИМОВ: ИСТОРИЧЕСКИЕ ПРИНЦИПЫ ПОЯВЛЕНИЯ ТЕРМИНА ХРЕМАТОНИМ И ДИАПАЗОН ХРЕМАТОНИМНОГО ПОЛЯ}

Аннотация. В последнее время актуализовалась проблематика, связанная с изучением имён собственных уникальных предметов - хрематонимов. Предметом нашего исследования являются ангийские хрематонимы с позиции их классификации и систематизации. Объектом - англиская онимная система. В украинской ономастической науке все еще не существует общепринятого представления о границах хрематонимии. Целью данной статьи является анализ существующих в лингвистике определений термина хрематоним, их сопоставление, унификация и стандартизация, выделение отдельных разрядов и классов хрематонимов, а также попутка проследить за изменениями разрядов от классического до современного состояния. Научная актуальность данной работы состоит в новом ракурсном изучении проблемы хрематонимии. В статье предложено определение термина хрематоним и создана классификая разряда хрематонимов.

Ключевые слова: оним, хрематоним, хрематономастика. 